\title{
Incentivizing the Use of Quantified Self Devices: The Cases of Digital Occupational Health Programs and Data-Driven Health Insurance Plans
}

\author{
Stefan Stepanovic ${ }^{1[0000-0002-4124-6643]}$ \\ ${ }^{1}$ Swiss Graduate School of Public Administration, \\ University of Lausanne, Lausanne, Switzerland \\ stefan.stepanovic@unil.ch
}

\begin{abstract}
Initially designed for a use in private settings, smartwatches, activity trackers and other quantified self devices are receiving a growing attention from the organizational environment. Firms and health insurance companies, in particular, are developing digital occupational health programs and data-driven health insurance plans centered around these systems, in the hope of exploiting their potential to improve individual health management, but also to gather large quantities of data. As individual participation in such organizational programs is voluntary, organizations often rely on motivational incentives to prompt engagement. Yet, little is known about the mechanisms employed in organizational settings to incentivize the use of quantified self devices. We therefore seek, in this exploratory paper, to offer a first structured overview of this topic and identify the main motivational incentives in two emblematical cases: digital occupational health programs and data-driven health insurance plans. By doing so, we aim to specify the nature of this new dynamic around the use of quantified self devices and define some of the key lines for further investigation.
\end{abstract}

Keywords: Motivational Incentives · Quantified Self Devices · Digital Occupational Health Programs · Data-Driven Health Insurance Plans.

\section{Introduction}

The use of wearable devices that allow individuals to track and monitor their personal health data is starting to become mainstream in industrialized countries $[1,2]$. For purposes of individual health, fitness, or well-being [3,4], interested parties can obtain a myriad of dedicated devices, ranging from low-cost activity trackers to wristbands, smartwatches and more complex biosensors [5]. These provide precise information about one's physical activity (e.g. calories burned, distance covered), health levels (e.g. quality of sleep, blood oxygenation) or personal performance (e.g. evolution in numbers of steps taken).

Engaging in the practice of automatically collecting personal data is generally referred to as quantified self; but also known under analogous terms such as self-tracking, lifelogging or life-hacking $[4,6]$. This practice builds upon the assumption that human bodies can be measured and understood through numbers [7] and that the knowledge of these numbers can enable each individual to discover, learn and act upon its attitudes 
and behaviors [8]. In the common understanding, quantified self practices are related to an individual use of systems in private settings: lifestyle gadgets and health products are designed for the consumer market and collected data is destined for private use only [9]. Yet, we are witnessing an emergence of third-party entities, such as government bodies, pharmaceutical industries, health insurance companies, healthcare suppliers or employers, that are integrating the relationship between the technology provider and the consumer [10-12]. They start to distribute these systems as part of their own programs; so more and more quantified self devices are embedded into medical programs supporting rehabilitation processes [13], chronic disease management [14], but also integrated into occupational health programs [15-17], or health insurance plans [10,11, 18]. These new actors are particularly attracted by the potential of quantified self devices in terms of self-care and positive impact on behavior. But they are also interested in the massive amount of detailed data that is generated by this technology [19]. Whereas in healthcare settings, it can be argued that enabling access to such a source of personal health information may be beneficial for the community [20] - as it allows, for example, a better monitoring of diseases or further research on new therapies - in other contexts, the use of quantified self devices may raise questions among users concerning the repurposing of the collected data for commercial or organizational goals. These potential exposures may concern a categorization of habits for marketing purposes [11], an identification of high-risk profiles to determine individualized pricings health premiums [21], or an institutionalization of syndromic surveillance for work productivity [20].

In order to mitigate these concerns, organizations often use motivational incentives, such as bonuses or rewards, to motivate people to participate in programs with quantified self devices [11]. Since participation in such organizational programs relies on a voluntary basis (given that these systems gather information that is potentially sensitive), organizations distributing quantified self devices to their employees and clients seek, through the implementation of incentives, to overcome resistance and increase adoption. Yet, little is known about the procedures that are put in place by these structures, as this represents a new and developing phenomena, both within practice and research [12].

Therefore, in this paper, we present an exploratory study on the mechanisms implemented by organizations to motivate individuals to participate in programs with quantified self devices. In contrast to conclusive studies, exploratory research is typically used as an initial appraisal, to provide a direction for future research and help to elaborate study designs [22]. Concretely, after introducing motivational incentives and their use in the Information Systems (IS) field, we particularly consider two practical cases (1) digital occupational health programs and (2) data-driven health insurance plans. These record a steady increase in use of quantified self devices, as reports indicate that (1) 13 million quantified self devices have been used in occupational health programs by 2018 and that up to 27,5 million are planned to be distributed by 2020 [17,23]; and that (2) among 221 health insurance companies in the world in 2015 [24], a majority of $60 \%$ had the intention to rapidly integrate this technology in their business plan (if not already done). For each case, we present our exploratory research design and provide 
the main results. We conclude by discussing these results, outlining the main learnings and proposing avenues for further research.

\section{Related Papers}

Since the early days of Taylorism at the beginning of the 20th century, incentives have been acknowledged as means to motivate individuals to perform tasks [25]. From the first monetary and financial remunerations, whole segments of research in psychology, organizational studies and behavioral economics have specialized into mechanisms that act on individual motivation. Most of this research builds upon the common division between intrinsic and extrinsic motivation, that refers to the nature of the motivation behind an action. Intrinsic motivation is linked to something inherently interesting or enjoyable, while extrinsic motivation refers to doing something because it leads to a separable outcome [26]. The latter has particularly led to incentive theory, which is one of the main theories of motivation [27]. It stipulates that individual behavior can be guided by external goals, such as recognition, rewards or money [28]. In the IS field, this theory has notably been apprehended through the lens of technology adoption, with Rogers [29] defining a typology of incentives that help individuals to embrace a new technology (and then eventually stick with it). He has notably classified incentives between monetary and non-monetary; immediate versus delayed (i.e. performing a task knowing that a reward will be given later) or positive or negative (i.e. praises, gratifications and rewards or, on the other end, punishments). Number of works have followed this path, with investigations on incentives applied to various fields, such as privacy and security information management (e.g. [30]), corporate performance (e.g. [e.g. 31]), but also for health improvement (e.g. [e.g. 32]).

Precisely, within the domain of quantified self devices, De Ridder, Kim, Jing, Khadra and Nanan [33] have conducted a systematic review of incentives for motivating people to use quantified self devices in the context of chronic disease self-management. Even though this work is rooted in a medical perspective (i.e. the user chose to use the device as part of a disease self-management), it offers a good basis for an examination of incentives offered by some types of organizations/institutions. In particular, it shows how organizations can build on the characteristics of quantified self devices (i.e. portability, connectivity, real-time reporting) to provide dialogue support to their users, i.e. evaluation of the use/performance (feedback); notice to engage with the use (reminder) or warning if there is a problematic element during the process (alert). Similarly, it associates social elements to connect users (social) as well as educational principles to provide information/training to prompt the use (education). Also, based on assumption that humans are attracted by playfulness and games in general [34], it can include fun components to make the use more enjoyable and entertaining (gamification). Finally, financial rewards can be added to provide an external source of motivation to engage in the use of quantified self devices (financial). Table 1 details these motivational incentives, as well as their general mechanisms and some concrete examples of application. 
Table 1. Typology of motivational incentives for quantified self devices, derived from [33].

\begin{tabular}{|c|c|c|}
\hline Motivational incentives & Incentive mechanisms & Application examples \\
\hline Feedback & $\begin{array}{l}\text { Informing the user about his } \\
\text { quantified self-practice }\end{array}$ & $\begin{array}{l}\text { Personalized messages, } \\
\text { individual counselling } \\
\text { sessions }\end{array}$ \\
\hline Reminder & $\begin{array}{l}\text { Systematically notifying the user } \\
\text { to engage in the quantified self } \\
\text { practice }\end{array}$ & SMS, push notifications \\
\hline Alert & $\begin{array}{l}\text { Warning the user about possible } \\
\text { issues related to his quantified } \\
\text { self practice }\end{array}$ & SMS, notices \\
\hline Social & Connecting users between them & $\begin{array}{l}\text { Forums, peer support } \\
\text { networks, peer messages }\end{array}$ \\
\hline Education & $\begin{array}{l}\text { Providing the user with } \\
\text { instructions, information and } \\
\text { training }\end{array}$ & $\begin{array}{l}\text { Online notes, leaflets, process } \\
\text { guidelines }\end{array}$ \\
\hline Gamification & $\begin{array}{l}\text { Adding a fun component to the } \\
\text { quantified self practice }\end{array}$ & Leaderboards, badges, avatars \\
\hline Financial & $\begin{array}{l}\text { Providing a financial } \\
\text { remuneration for the quantified } \\
\text { self practice }\end{array}$ & $\begin{array}{l}\text { Cashback, value points, } \\
\text { vouchers }\end{array}$ \\
\hline
\end{tabular}

\section{Case 1: Incentives in Digital Occupational Health Programs}

\subsection{Research Design}

Firms are considered to be very early adopters of quantified self devices in the organizational environment: they have started since the 2010s to examine the capacity of quantified self devices to tackle one of their largest cost factor, employees' health and safety, while providing an opportunity to gather information on their workforce [20]. Accordingly, we decided to look at the published academic literature to gain some insights on the current state of research. We thus conducted a scoping literature review of the incentives that are employed by firms to motivate employees to participate in programs with quantified self devices. This form of literature review serves as a preliminary assessment of the state-of-the-art, while remaining transparent, methodical and replicable [35]. The mechanisms are similar to systematic reviews, as we methodically searched academic articles in relevant electronic databases. In our case, we determined the following search string "quantified self" OR "self-tracking" OR physiolytics OR lifelogging OR wearable health device OR fitness tracker OR activity tracker AND corporat* OR work* OR organization* AND incentiv* OR motivation* OR reward and applied it to title, abstract and keywords screening in the principal databases for IS literature (AISeL), computing and information technology (ACM), as well as in one of the main cross-disciplinary databases (Web of knowledge).We specifically 
targeted empirical papers (journal and full conference papers) and limited our research to publications which were published in English. Finally, we excluded studies that had no direct link with quantified self devices and digital occupational health programs. By means of our database search, we identified 86 records from AISeL, 17 from ACM, and 80 from Web of knowledge. After removing duplicates, screening titles, abstracts and keywords, and applying our inclusion/exclusion criteria, we obtained a list of 12 publications which met our above-mentioned requirements (cf. Table 2).

\subsection{Results}

One of the striking elements is the prevalence of feedback incentives in our selected studies. Arguably, due to the design of quantified self devices, a form of feedback incentive is essentially present in every program based on these systems (i.e. the user can see the data provided by the device), yet all of the identified occupational programs also propose a form of interactive feedback [e.g. 36] or individual counselling sessions [e.g. 37]. These are commonly associated with other motivational incentives, primarily with financial remuneration or gamification, but also with education (to support the communication, advices and problem-solving). In fact, out of these 12 selected studies, 6 included a form of financial incentive that provides cash rewards or vouchers (if defined goals regarding physical activity are attained). These goals generally take the form of daily objectives (e.g. averaging a certain number of steps a day) or improved biometric levels (e.g. Body Mass Index under a certain figure). Also, such incentive schemes are often associated to virtual value points, creating an intermediary currency between physical activity and its economic value. Their aim is to make it easier for participants to understand, follow and measure their progress and achievements. In terms of effectiveness, all studies reported positive results for financial incentives in promoting a participation in the beginning of the digital occupational health program, although this effect is sometimes marginal [e.g. 38]. Yet, two studies [39, 40] questioned the effects of financial incentives on the individual long-term participation (more than 6 months) as well as the durability of this approach in a digital occupational health program. Another popular motivational incentive consisted in relying on gamification, with a third of our selected publications applying such a mechanism. Virtual points also constituted a key element in the structure of these incentives: they translate users' physical activity into a metric, that is used, in this case, for leaderboards and classifications. Building on a competitive spirit of participants, these leaderboards aim to increase users' appeal to play and leverage a dynamic participation. As for incentives, gamification is found to have a positive effect on the engagement in the first phases, but there are still interrogations about the sustainability of this approach [e.g. 41]. A brief review of the retained studies can be found in Table 2 . 
Table 2. Selected studies for review.

\begin{tabular}{|c|c|c|c|c|}
\hline Publications & $\begin{array}{l}\text { Study sample } \\
\text { and duration }\end{array}$ & $\begin{array}{l}\text { Motivational } \\
\text { incentives }\end{array}$ & Incentive mechanisms & $\begin{array}{l}\text { Incentive } \\
\text { evaluations }\end{array}$ \\
\hline $\begin{array}{l}\text { Chung et al. } \\
(2017) \\
{[39]}\end{array}$ & $\begin{array}{l}504 \text { partici- } \\
\text { pants, } 12 \\
\text { months }\end{array}$ & $\begin{array}{l}\text { Feedback, } \\
\text { Financial }\end{array}$ & $\begin{array}{l}\text { Virtual points are given } \\
\text { according to users' phys- } \\
\text { ical activity levels ( } 1 \text { step } \\
=1 \text { point) or if activity } \\
\text { goals are attained in a } \\
\text { given time (e.g. averag- } \\
\text { ing } 7,000 \text { steps per day). } \\
\text { These virtual points can } \\
\text { be exchanged for cash } \\
\text { rewards, gift cards or in- } \\
\text { surance discounts. }\end{array}$ & $\begin{array}{l}\text { Effectively } \\
\text { motivate us- } \\
\text { ers in the } \\
\text { first phases } \\
\text { to motivate } \\
\text { users, sus- } \\
\text { tainability } \\
\text { has to be in- } \\
\text { vestigated. }\end{array}$ \\
\hline $\begin{array}{l}\text { Coffeng et } \\
\text { al. } \\
(2017) \\
{[42]}\end{array}$ & $\begin{array}{l}750 \text { partici- } \\
\text { pants, } 30 \\
\text { months }\end{array}$ & $\begin{array}{l}\text { Education, } \\
\text { Feedback }\end{array}$ & $\begin{array}{l}\text { Coaching feedback ses- } \\
\text { sions }\end{array}$ & $\begin{array}{l}\text { To be deter- } \\
\text { mined }\end{array}$ \\
\hline $\begin{array}{l}\text { Gilson et al. } \\
(2016) \\
{[43]}\end{array}$ & $\begin{array}{l}19 \text { partici- } \\
\text { pants, } 20 \\
\text { weeks }\end{array}$ & $\begin{array}{l}\text { Feedback, } \\
\text { Financial }\end{array}$ & $\begin{array}{l}\text { Virtual points are given } \\
\text { if physical activity goals } \\
\text { are attained (e.g. averag- } \\
\text { ing a number of steps per } \\
\text { day). These virtual points } \\
\text { can be transformed in } \\
\text { vouchers. }\end{array}$ & $\begin{array}{l}\text { Small posi- } \\
\text { tive changes } \\
\text { for a majority } \\
\text { of users }\end{array}$ \\
\hline $\begin{array}{l}\text { Gomez-Car- } \\
\text { mona and al. } \\
(2017) \\
{[36]}\end{array}$ & $\begin{array}{l}4 \text { partici- } \\
\text { pants, } 1 \\
\text { week. }\end{array}$ & $\begin{array}{l}\text { Feedback, } \\
\text { Gamification. }\end{array}$ & $\begin{array}{l}\text { Motivational advice re- } \\
\text { lated to physical perfor- } \\
\text { mance, leaderboards. }\end{array}$ & $\begin{array}{l}\text { Effectively } \\
\text { motivate us- } \\
\text { ers in the } \\
\text { first phases }\end{array}$ \\
\hline $\begin{array}{l}\text { Hunter et al. } \\
(2016) \\
{[40]}\end{array}$ & $\begin{array}{l}853 \text { partici- } \\
\text { pants, } 13 \\
\text { months. }\end{array}$ & $\begin{array}{l}\text { Feedback, } \\
\text { Financial }\end{array}$ & $\begin{array}{l}\text { Virtual points are given } \\
\text { according minutes of } \\
\text { physical activity ( } 1 \text { min } \\
\text { of activity recorded=1 } \\
\text { point). These virtual } \\
\text { points can be exchanged } \\
\text { for vouchers. }\end{array}$ & $\begin{array}{l}\text { Effective af- } \\
\text { ter } 4 \text { weeks, } \\
\text { after } 6 \\
\text { months no } \\
\text { significant } \\
\text { differences } \\
\text { with the con- } \\
\text { trol group }\end{array}$ \\
\hline $\begin{array}{l}\text { Jelsma et al. } \\
(2019) \\
{[37]}\end{array}$ & $\begin{array}{l}250 \text { partici- } \\
\text { pants, } 12 \\
\text { months }\end{array}$ & $\begin{array}{l}\text { Feedback, } \\
\text { Education }\end{array}$ & $\begin{array}{l}\text { Face to face sessions, in- } \\
\text { dividual counselling, } \\
\text { self-help program leaflet }\end{array}$ & $\begin{array}{l}\text { To be deter- } \\
\text { mined }\end{array}$ \\
\hline
\end{tabular}




\begin{tabular}{|c|c|c|c|c|}
\hline Publications & $\begin{array}{l}\text { Study sample } \\
\text { and duration }\end{array}$ & $\begin{array}{l}\text { Motivational } \\
\text { incentives }\end{array}$ & Incentive mechanisms & $\begin{array}{l}\text { Incentive } \\
\text { evaluations }\end{array}$ \\
\hline $\begin{array}{l}\text { Kim et al. } \\
(2016) \\
{[41]}\end{array}$ & $\begin{array}{l}455341 \text { par- } \\
\text { ticipants, } 12 \\
\text { months }\end{array}$ & $\begin{array}{l}\text { Feedback, } \\
\text { Financial, } \\
\text { Gamification }\end{array}$ & $\begin{array}{l}\text { Various challenges re- } \\
\text { garding physical activity, } \\
\text { rewards platform where } \\
\text { gains can be collected }\end{array}$ & $\begin{array}{l}\text { Difficult to } \\
\text { prove the } \\
\text { role of incen- } \\
\text { tives, alt- } \\
\text { hough partic- } \\
\text { ipation is en- } \\
\text { hanced }\end{array}$ \\
\hline $\begin{array}{l}\text { Lin et al. } \\
(2006) \\
{[44]}\end{array}$ & $\begin{array}{l}19 \text { partici- } \\
\text { pants, } 14 \\
\text { weeks }\end{array}$ & $\begin{array}{l}\text { Feedback, } \\
\text { Gamification, } \\
\text { Social }\end{array}$ & $\begin{array}{l}\text { Daily users' steps are re- } \\
\text { lated to the growth of an } \\
\text { animated virtual charac- } \\
\text { ter }\end{array}$ & $\begin{array}{l}\text { Effective as } \\
\text { users have } \\
\text { established } \\
\text { new routines } \\
\text { with positive } \\
\text { impact on } \\
\text { their physical } \\
\text { activity and } \\
\text { health levels }\end{array}$ \\
\hline $\begin{array}{l}\text { Lee et al. } \\
(2019) \\
{[45]}\end{array}$ & $\begin{array}{l}79 \text { partici- } \\
\text { pants, } 12 \\
\text { weeks }\end{array}$ & $\begin{array}{l}\text { Feedback, } \\
\text { Reminder }\end{array}$ & $\begin{array}{l}\text { Daily motivational text } \\
\text { messaging, biweekly } \\
\text { counseling and a specifi- } \\
\text { cally designed workbook } \\
\text { for } 12 \text { weeks }\end{array}$ & $\begin{array}{l}\text { Counseling } \\
\text { and tailored } \\
\text { text messag- } \\
\text { ing are effec- } \\
\text { tive for phys- } \\
\text { ically inac- } \\
\text { tive users }\end{array}$ \\
\hline $\begin{array}{l}\text { Patel et al. } \\
(2016) \\
{[46]}\end{array}$ & $\begin{array}{l}304 \text { partici- } \\
\text { pants, } 26 \\
\text { weeks }\end{array}$ & Financial & $\begin{array}{l}\text { Various challenges re- } \\
\text { garding physical activity. } \\
\text { Individual and team per- } \\
\text { formance are rewarded } \\
\text { by cash prizes }\end{array}$ & $\begin{array}{l}\text { Effective in } \\
\text { increasing } \\
\text { physical ac- } \\
\text { tivity }\end{array}$ \\
\hline $\begin{array}{l}\text { Vyas et al. } \\
(2015) \\
{[15]}\end{array}$ & $\begin{array}{l}17 \text { partici- } \\
\text { pants, } 100 \\
\text { days }\end{array}$ & $\begin{array}{l}\text { Feedback } \\
\text { Gamification }\end{array}$ & $\begin{array}{l}\text { Through a step counting } \\
\text { mechanisms, participants } \\
\text { can unlock trophies, } \\
\text { leaderboards }\end{array}$ & $\begin{array}{l}\text { Positive re- } \\
\text { sults, motiva- } \\
\text { tion en- } \\
\text { hanced }\end{array}$ \\
\hline $\begin{array}{l}\text { Yu et al. } \\
(2019) \\
{[38]}\end{array}$ & $\begin{array}{l}1,436 \text { partici- } \\
\text { pants, be- } \\
\text { tween } 2011 \\
\text { and } 2014\end{array}$ & $\begin{array}{l}\text { Feedback, } \\
\text { Financial }\end{array}$ & $\begin{array}{l}\text { Achieving certain health } \\
\text { standards based on bio- } \\
\text { metric screening values } \\
\text { (e.g., Body Mass Index } \\
\text { of } 18.5-27.5 \text { ) is re- } \\
\text { warded by cash prizes }\end{array}$ & $\begin{array}{l}\text { Statistically } \\
\text { little impact }\end{array}$ \\
\hline
\end{tabular}




\section{Case 2: Incentives in Data-Driven Health Insurance Plans}

\subsection{Research Design}

In liberal healthcare markets such as Germany, the Netherlands or Australia, health insurance companies have just begun to propose additional health plans that include quantified self devices [47]. Consequently, there is little academic evidence which can be assessed based on a literature analysis. Therefore, we decided to review offerings from major health insurance companies. The idea was to explore if plans with quantified self devices are proposed and if so, reference what kind of incentives are included. We decided to focus on Switzerland, as it has a liberal market with a high competition between health insurance companies: permanent residents can enroll in extra health insurance plans (such as data-driven health plans) in addition to a standard insurance plan that covers basic healthcare costs, i.e. examination and treatment of a medical condition and its consequences. There are therefore expectations with respect to choice options for the side of consumers, particularly as Swiss are often well-equipped in terms of Information Technology, financially well-off and generally early adopter of consumer technology. To review offerings, we based our research on the official directory of health insurance companies made by the Federal Office of Public Health ${ }^{1}$. We concentrate on the five biggest health insurance companies ( $>500^{\prime} 000$ clients), which account for two thirds of the Swiss market share and therefore offer a representative picture of what type of data-driven insurance plans individuals may obtain in Switzerland.

\subsection{Results}

Out of the 5 major Swiss health insurance companies (Assura, CSS, Helsana, Swica, Concordia), 3 offer plans with quantified self devices (i.e. CSS, Helsana, Swica). They display similar practices by offering to participants to link a quantified self device to their dedicated app and therefore open the possibility for a financial gain on healthcare costs and premiums. Concretely, through its program myStep, CSS compensates with CHF 0.20 (ф20) each day when users do between 7500 steps and 9999 steps, and with CHF 0.40 ( $\varnothing 40)$ each day when they do more than 10000 steps [48]. Similarly, Helsana offers to consumers to connect with a Garmin or a Fitbit to their app Helsana+ in order to collect so-called Plus points. A plus point is commonly obtained if users attain during the day one of the following values: 10000 steps, a pulse rate of 110 per minute for 30 minutes or 150 calories burned in 30 minutes [49]. These points may then be converted into cashback, reductions or gifts, allowing consumers to earn/save up to CHF 300 (\$300) a year. Finally, Swica offers through its Benevita program a possibility to automatically gather quantified self data and complete an online form with health/lifestyle related questions to gather bonus points in order to save up to $15 \%$ of the premium [50]. It also proposes lifestyle challenges and fun games that users can share with other users,

1 Statistique de l'assurance maladie 2019, URL : https://www.bag.admin.ch/bag/fr/home/zahlen-und-statistiken/statistiken-zur-krankenversicherung.html 
as well as possibilities to retrieve educational content (regarding, for instance, physical exercises or nutrition).

Table 3. Selected plans for review.

\begin{tabular}{lll}
\hline $\begin{array}{l}\text { Health insurance } \\
\text { companies }\end{array}$ & Motivational incentives & Incentive mechanisms \\
\hline CSS [48] & Financial & $\begin{array}{l}\text { Amount of money is credited each time } \\
\text { a defined goal is achieved. } \\
\text { Points are collected each time a defined } \\
\text { goal/challenge is achieved. Points can be } \\
\text { transformed into discounts or vouchers. }\end{array}$ \\
& $\begin{array}{l}\text { Feedback, Financial, } \\
\text { Gamification }\end{array}$ & $\begin{array}{l}\text { Points are collected each time a defined } \\
\text { goal/challenge is achieved. Challenges } \\
\text { can be shared with other participants. } \\
\text { Through the app, clients can retrieve in- } \\
\text { formative leaflets on nutrition or physi- } \\
\text { cal activity. Points can be transformed } \\
\text { into discounts or vouchers. }\end{array}$ \\
\hline Ewica [50] & Gamification, Social & \\
& &
\end{tabular}

\section{Discussion and Key Implications for Future Research}

The starting point of this explorative study is that organizations, such as firms and health insurance companies, increasingly include quantified self devices in their operations and often resort to motivational incentives to incite individuals to adopt and return to their quantified self solution [33]. Our findings show that similarities exist between digital occupational health programs and data-driven health plans in how they encourage users to participate in their respective programs. First, drawing on the design and capabilities of quantified self devices (i.e. enabling automatic flows of information about one's health levels), organizations commonly provide a feedback loop to assist participants in their tracking. This is particularly prevalent in workplace settings where firms often propose individual counselling or personalized messages as part of their digital occupational health program. This may be explained by the necessity for firms to communicate through the whole process: they need to reassure employees or clients regarding their engagement to improve their health behavior. As we have seen, quantified self devices may create a tension between leisure and work contexts as they gather, independently of context, data about one's physical activity and lifestyle [7]. So, it is essential for firms to show to their employees the added value such devices provide as well as offer help in interpreting and understanding the collected data and what is further done with it. Simultaneously, it offers to firms a way to monitor the effectiveness of the occupational program and refine the global picture regarding workforce health levels.

Our results also indicate that feedback mechanisms are commonly associated with other incentives, especially financial incentives and gamification. The extensive use of 
financial incentives reveals that organizations consider that existing benefits (promises that the user may improve his health levels) are still not sufficient to prompt individuals to use quantified self devices in organizational programs [11]. They therefore build their motivational strategies on external rewards, which are typically used when the barriers to adoption are perceived as high, or when the defined objectives are considered difficult to be achieved [51]. Our exploratory study suggests that, in workplace settings, financial incentives have a positive effect in the first phases of engagement with quantified self devices, although the sustainability of this approach remains questionable on the long run. This is in line with reports (e.g. [52]) that showed that financial incentives potentially reduce intrinsic motivation (even if the interest is initially high) and undermine performance once the incentive is removed or lowered. Yet, a long-term use of quantified self devices is crucial in organizational programs, both for organizations and for participants. It ensures that enough data is gathered and that this data can be used for meaningful analyses and feedback. In this way, it may raise awareness regarding health levels and potentially support an individual behavior change (which is generally a lasting process). In consequence, for digital occupational health programs, further research may focus on unveiling the long-term effectiveness of financial incentives, in order to clearly assess the scope of (positive) impact of this incentive. For data-driven health plans, the systematic use of financial incentives demonstrates the high importance given by health insurance companies to this particular mechanism. Further analysis may therefore be oriented to thoughtfully consider the ramifications of this motivational incentive: does it increase individuals' participation? If so, is there a population group that is more prone to subscribe to such plan? What are the implications in terms of participants' privacy? And, as for digital occupational health programs, do financial incentives foster a long-term engagement in data-driven health plans?

Finally, our review indicates that gamification also represents a frequent motivational incentive. This is in line with the popularity of gamification as a design approach to address motivational issues for commercial and medical purposes [34]. Its implementation in organizations mainly consists in easing the execution of actions that are associated with a positive lifestyle (e.g. points-based scheme that translate the number of steps per day) and promoting the consistent of quantified-devices (e.g. extra points if performed on consecutive days) [53]. Nonetheless, gamification, as a motivational incentive, encounters similar challenges as financial incentives: evidence shows that it may have a positive impact on the use of quantified self devices in the first weeks, but its long-term impact is still not evident. In fact, some figures and numbers suggest that gamified interactive systems for health behavior change are considered as successful in merely $50 \%$ of the cases [54]. It seems therefore important to further assess the capacity of gamification to foster long-term engagement with quantified self devices, and then consider its application in organizational environments.

In sum, quantified self devices are emerging in organizational environments and lots of opportunities for research are arising with them. Various perspectives (e.g. organizational vs. individual) and approaches (e.g. utilitarian vs. hedonic) can be adopted and developed. So, we hope that, through this explorative study, we have indicated some of the paths worth investigating; and that these paths may ultimately lead to the 
development of effective digital programs for organizations as well as harmonious environments for individual health.

Acknowledgements. This research has been supported by the Swiss National Science Foundation (SNSF) grant no. 172740.

\section{References}

1. Kunze, K., Iwamura, M., Kise, K., Uchida, S., Omachi, S.: Activity recognition for the mind: Toward a cognitive" Quantified Self". Computer 46(10), 105-108 (2013).

2. Starner, T.: How wearables worked their way into the mainstream. IEEE Pervasive Computing 13(4), 10-15 (2014).

3. Lupton, D.: Self-tracking modes: Reflexive self-monitoring and data practices. In: Proceedings of the 2015 Social Life of Big Data Symposium, pp. 1-19 (2014).

4. Pfeiffer, J., von Entress-Fuersteneck, M., Urbach, N., Buchwald, A.: Quantify-me: Consumer Acceptance of Wearable Self-tracking Devices. In: Proceedings of the 24th European Conference on Information Systems pp. 1-15 (2016).

5. Patel, M.S., Asch, D.A., Volpp, K.G.: Wearable devices as facilitators, not drivers, of health behavior change. Journal of the American Medical Association 313(5), 459-460 (2015).

6. Calvard, T.: Integrating Social Scientific Perspectives on the Quantified Employee Self. Social Sciences 8(9), 1-19 (2019).

7. Whitson, J.R.: Gaming the quantified self. Surveillance \& Society 11(1/2), 163-176 (2013)

8. Choe, E.K., Lee, N.B., Lee, B., Pratt, W., Kientz, J.A.: Understanding quantified-selfers' practices in collecting and exploring personal data. In: Proceedings of the 32nd annual ACM conference on Human factors in computing systems, pp. 1143-1152 (2014).

9. Gabriels, K., Moerenhout, T.: Exploring entertainment medicine and professionalization of self-care: interview study among doctors on the potential effects of digital self-tracking. Journal of medical Internet research 20(1), 1-12 (2018).

10. Paluch, S., Tuzovic, S.: Persuaded self-tracking with wearable technology: carrot or stick? Journal of Services Marketing 33(4), 436-448 (2019).

11. Tedesco, S., Barton, J., O'Flynn, B.: A review of activity trackers for senior citizens: Research perspectives, commercial landscape and the role of the insurance industry. Sensors 17(6), 1-39 (2017).

12. Ajana, B.: Digital health and the biopolitics of the Quantified Self. Digital Health 3(1), 1-18 (2017).

13. Appelboom, G., Camacho, E., Abraham, M.E., Bruce, S.S., Dumont, E.L., Zacharia, B.E., D’Amico, R., Slomian, J., Reginster, J.Y., Bruyère, O.: Smart wearable body sensors for patient self-assessment and monitoring. Archives of public health 72(28), 1-9 (2014).

14. Chiauzzi, E., Rodarte, C., DasMahapatra, P.: Patient-centered activity monitoring in the selfmanagement of chronic health conditions. BMC Medicine 13(77), 1-6 (2015).

15. Vyas, D., Fitz-Walter, Z., Mealy, E., Soro, A., Zhang, J., Brereton, M.: Exploring physical activities in an employer-sponsored health program. In: Proceedings of the 33rd Annual ACM Conference Extended Abstracts on Human Factors in Computing Systems, pp. 1421$1426(2015)$.

16. Gorm, N., Shklovski, I.: Steps, choices and moral accounting: Observations from a stepcounting campaign in the workplace. In: Proceedings of the 2016 ACM Conference on Computer-Supported Cooperative Work \& Social Computing, pp. 148-159 (2016). 
17. Olson, P.: More Bosses Expected To Track Their Staff Through Wearables In The Next 5 Years https://www.forbes.com/sites/parmyolson/2015/06/01/wearables-employee-tracking/

18. Mettler, T., Wulf, J.: Health promotion with physiolytics: What is driving people to subscribe in a data-driven health plan. Plos one 15(4), 1-19 (2020).

19. Silvello, A., Procaccini, A.: Connected Insurance Reshaping the Health Insurance Industry. Smart Healthcare, pp. 1-12. IntechOpen, n/d (2019).

20. Lupton, D.: The diverse domains of quantified selves: self-tracking modes and dataveillance. Economy and Society 45(1), 101-122 (2016).

21. Constantiou, I.D., Kallinikos, J.: New games, new rules: big data and the changing context of strategy. Journal of Information Technology 30(1), 44-57 (2015).

22. Singh, K.: Quantitative social research methods. Sage, New Dehli (2007).

23. Giddens, L., Gonzalez, E., Leidner, D.: I track, therefore I Am: exploring the impact of wearable fitness devices on employee identity and well-being. In: Proceedings of the 22th Americas Conference on Information Systems, pp. 1-5 (2016).

24. Accenture: Digital insurance era: Stretch your boundaries. https://www.accenture.com/_acnmedia/pdf-51/accenture-technology-vision-for-insurance-2015-full-report-pov.pdf, last accessed 01/04/2020.

25. Harunavamwe, M., Kanengoni, H.: The impact of monetary and non-monetary rewards on motivation among lower level employees in selected retail shops. African Journal of Business Management 7(38), 3929 (2013).

26. Ryan, R.M., Deci, E.L.: Intrinsic and extrinsic motivations: Classic definitions and new directions. Contemp Educ Psychol 25(1), 54-67 (2000).

27. Bretschneider, U., Leimeister, J.M.: Not just an ego-trip: Exploring backers' motivation for funding in incentive-based crowdfunding. The Journal of Strategic Information Systems 26(4), 246-260 (2017).

28. Hockenbury, D.H., Hockenbury, S.E.: Discovering psychology. Macmillan, New York (2010).

29. Rogers, E.M.: Diffusion of innovations. Simon and Schuster, New York (2010).

30. Gal-Or, E., Ghose, A.: The economic incentives for sharing security information. Information Systems Research 16(2), 186-208 (2005).

31. O'Byrne, S., Young, D.: Top management incentives and corporate performance. Journal of Applied Corporate Finance 17(4), 105-114 (2005).

32. Doolan, D.F., Bates, D.W.: Computerized physician order entry systems in hospitals: mandates and incentives. Health affairs 21(4), 180-188 (2002).

33. De Ridder, M., Kim, J., Jing, Y., Khadra, M., Nanan, R.: A systematic review on incentivedriven mobile health technology: as used in diabetes management. Journal of telemedicine and telecare 23(1), 26-35 (2017).

34. Hamari, J.: Transforming homo economicus into homo ludens: A field experiment on gamification in a utilitarian peer-to-peer trading service. Electron Commer R A 12(4), 236-245 (2013).

35. Munn, Z., Peters, M.D., Stern, C., Tufanaru, C., McArthur, A., Aromataris, E.: Systematic review or scoping review? Guidance for authors when choosing between a systematic or scoping review approach. BMC medical research methodology 18(143), 1-7 (2018).

36. Gomez-Carmona, O., Casado-Mansilla, D.: SmiWork: An interactive smart mirror platform for workplace health promotion. In: Proceedings of the 2nd International Multidisciplinary Conference on Computer and Energy Science (SpliTech), pp. 1-6 (2017).

37. Jelsma, J.G., Renaud, L.R., Huysmans, M.A., Coffeng, J.K., Loyen, A., Van Nassau, F., Bosmans, J.E., Speklé, E.M., Van Der Beek, A.J., Van Der Ploeg, H.P.: The Dynamic Work study: study protocol of a cluster randomized controlled trial of an occupational health 
intervention aimed at reducing sitting time in office workers. BMC Public Health 19(188), 1-13 (2019).

38. Yu, Y., Yan, X., Zhang, X., Zhou, S.: What They Gain Depends on What They Do: An Exploratory Empirical Research on Effective Use of Mobile Healthcare Applications. In: Proceedings of the 52nd Hawaii International Conference on System Sciences, pp. 39803989 (2019).

39. Chung, C.-F., Jensen, N., Shklovski, I.A., Munson, S.: Finding the right fit: Understanding health tracking in workplace wellness programs. In: Proceedings of the 2017 Conference on Human Factors in Computing Systems, pp. 4875-4886. (2017).

40. Hunter, R.F., Brennan, S.F., Tang, J., Smith, O.J., Murray, J., Tully, M.A., Patterson, C., Longo, A., Hutchinson, G., Prior, L.: Effectiveness and cost-effectiveness of a physical activity loyalty scheme for behaviour change maintenance: a cluster randomised controlled trial. BMC public health 16(1), 618 (2016).

41. Kim, J.Y., Wineinger, N.E., Taitel, M., Radin, J.M., Akinbosoye, O., Jiang, J., Nikzad, N., Orr, G., Topol, E., Steinhubl, S.: Self-monitoring utilization patterns among individuals in an incentivized program for healthy behaviors. Journal of medical Internet research 18(11), $1-15$ (2016).

42. Coffeng, J.K., Van der Ploeg, H.P., Castellano, J.M., Fernández-Alvira, J.M., Ibáñez, B., Garcia-Lunar, I., Van der Beek, A.J., Fernandez-Ortiz, A., Mocoroa, A., Garcia-Leal, L.: A 30-month worksite-based lifestyle program to promote cardiovascular health in middle-aged bank employees: Design of the TANSNIP-PESA randomized controlled trial. American Heart Journal 184(1) 121-132 (2017).

43. Gilson, N.D., Pavey, T.G., Vandelanotte, C., Duncan, M.J., Gomersall, S.R., Trost, S.G., Brown, W.J.: Chronic disease risks and use of a smartphone application during a physical activity and dietary intervention in Australian truck drivers. Australian and New Zealand journal of public health 40(1), 91-93 (2016).

44. Lin, J.J., Mamykina, L., Lindtner, S., Delajoux, G., Strub, H.B.: Fish'n'Steps: Encouraging physical activity with an interactive computer game. In: Proceedings of the 2017 International Conference on Ubiquitous Computing, pp. 261-278. (2006).

45. Lee, S.-H., Ha, Y., Jung, M., Yang, S., Kang, W.-S.: The Effects of a Mobile Wellness Intervention with Fitbit Use and Goal Setting for Workers. Telemedicine and e-Health 25(11), 1115-1122 (2019).

46. Patel, M.S., Asch, D.A., Rosin, R., Small, D.S., Bellamy, S.L., Eberbach, K., Walters, K.J., Haff, N., Lee, S.M., Wesby, L.: Individual versus team-based financial incentives to increase physical activity: a randomized, controlled trial. Journal of general internal medicine 31(7), 746-754 (2016).

47. Henkel, M., Heck, T., Göretz, J.: Rewarding Fitness Tracking-The Communication and Promotion of Health Insurers' Bonus Programs and the Use of Self-tracking Data. In: Proceedings of the 2018 International Conference on Social Computing and Social Media, pp. 28-49 (2018).

48. CSS: MyStep - chaque pas compte https://www.css.ch/fr/home/privatpersonen/kontakt_service/mycss/mystep.html, last accessed 01/04/2020

49. Helsana: Nous récompensons votre mode de vie sain. Avec l'app Helsana+. https://www.helsana.ch/microsite/plus/\#/, 01/04/2020

50. Swica: Benevita. https://www.benevita.ch, 01/04/2020

51. Norman, G.J., Heltemes, K.J., Heck, D., Osmick, M.J.: Employee use of a wireless physical activity tracker within two incentive designs at one company. Population health management 19(2), 88-94 (2016). 
52. Promberger, M., Marteau, T.M.: When do financial incentives reduce intrinsic motivation? Comparing behaviors studied in psychological and economic literatures. Health Psychology 32(9), 950-957 (2013).

53. Alahäivälä, T., Oinas-Kukkonen, H.: Understanding persuasion contexts in health gamification: A systematic analysis of gamified health behavior change support systems literature. International Journal of Medical Informatics 96(62-70 (2016).

54. Hamari, J., Koivisto, J., Sarsa, H.: Does Gamification Work? - A Literature Review of Empirical Studies on Gamification. In: Proceedings of the 47th Hawaii International Conference on System Sciences, pp. 3025-3034 (2014). 